\title{
Vitamin D Deficiency is Associated with Handgrip Strength, Nutritional Status and T2DM in Community-Dwelling Older Mexican Women: A Cross-Sectional Study
}

\author{
Luciano Mendoza-Garcés ${ }^{1, *,+}$, María Consuelo Velázquez-Alva ${ }^{2,+}{ }^{\circledR}$, María Fernanda Cabrer-Rosales ${ }^{2}$, \\ Isabel Arrieta-Cruz ${ }^{1}$, Roger Gutiérrez-Juárez ${ }^{3}$ and María Esther Irigoyen-Camacho ${ }^{2, *}$ \\ 1 National Institute of Geriatrics, Ministry of Health, Mexico City 10200, Mexico; iarrieta@inger.gob.mx \\ 2 Health Care Department, Metropolitan Autonomous University, Unit Xochimilco, Mexico City 04960, Mexico; \\ mcvelaz@correo.xoc.uam.mx (M.C.V.-A.); mcabrer@correo.xoc.uam.mx (M.F.C.-R.) \\ 3 Department of Biomedical Sciences, School of Medicine, Faculty of Higher Studies Zaragoza, \\ National Autonomous University of Mexico, Mexico City 09230, Mexico; roger.gutierrez@zaragoza.unam.mx \\ * Correspondence: lmendoza@inger.gob.mx (L.M.-G.); meirigo@correo.xoc.uam.mx (M.E.I.-C.) \\ + These authors contributed equally to this work.
}

check for updates

Citation: Mendoza-Garcés, L.;

Velázquez-Alva, M.C.;

Cabrer-Rosales, M.F.; Arrieta-Cruz, I.; Gutiérrez-Juárez, R.;

Irigoyen-Camacho, M.E. Vitamin D

Deficiency is Associated with

Handgrip Strength, Nutritional Status and T2DM in Community-Dwelling Older Mexican Women: A

Cross-Sectional Study. Nutrients 2021,

13, 736. https://doi.org/10.3390/

nu13030736

Academic Editor: Deborah Agostini

Received: 22 December 2020

Accepted: 22 February 2021

Published: 26 February 2021

Publisher's Note: MDPI stays neutral with regard to jurisdictional claims in published maps and institutional affiliations.

Copyright: (c) 2021 by the authors. Licensee MDPI, Basel, Switzerland. This article is an open access article distributed under the terms and conditions of the Creative Commons Attribution (CC BY) license (https:// creativecommons.org/licenses/by/ $4.0 /)$.

\begin{abstract}
The aim of this study was to evaluate the association between handgrip strength, nutritional status and vitamin D deficiency in Mexican community-dwelling older women. A cross sectional study in women $\geq 60$ years-old was performed. Plasma 25 -hydroxyvitamin $\mathrm{D}(25(\mathrm{OH}) \mathrm{D})$ concentrations were measured by a quantitative immunoassay technique. Handgrip strength was assessed using a dynamometer, while nutritional status was assessed through the Full Mini Nutritional Assessment (Full-MNA). A total of 116 women participated in the study, their mean age was $70.3 \pm 5.8$ years; $49.1 \%$ of the study group had plasma $25(\mathrm{OH}) \mathrm{D}$ levels lower than $40 \mathrm{nmol} / \mathrm{L}$ [16 ng/mL]. Meanwhile, $28.45 \%$ of participants had low handgrip strength $(<16 \mathrm{~kg})$, and $23.1 \%$ were identified at risk of malnutrition/malnourished according with Full-MNA score. Women with 25(OH)D deficiency $(<40 \mathrm{nmol} / \mathrm{L}[16 \mathrm{ng} / \mathrm{mL}])$ were more likely to have low handgrip strength $(\mathrm{OR}=2.64, p=0.025)$ compared with those with higher $25(\mathrm{OH}) \mathrm{D}$ values. Additionally, being malnourished or at risk of malnutrition $(\mathrm{OR}=2.53, p=0.045)$ or having type 2 diabetes mellitus (T2DM) $(\mathrm{OR}=2.92, p=0.044)$ was also associated with low $25(\mathrm{OH}) \mathrm{D}$. The prevalence of low plasma $25(\mathrm{OH}) \mathrm{D}$ concentrations was high among Mexican active older women. Low handgrip strength, being at risk of malnutrition/malnourished, or diagnosed with T2DM was also associated with Vitamin D deficiency.
\end{abstract}

Keywords: vitamin D deficiency; handgrip strength; muscle skeletal health; full mini nutritional assessment; aging; community dwelling

\section{Introduction}

Vitamin $\mathrm{D}$ is a steroid hormone that plays an important role in various physiological processes due to its pleiotropic effects on cells of several biological systems, such as the immune, cardiovascular, intestinal or skeletal muscle system. Relevant functions of vitamin $\mathrm{D}$ include synthesis of calcium-binding proteins and modulation of contractility in cardiomyocytes, proper absorption of calcium and phosphate ions in the intestinal epithelium as well as bone remodeling and mineralization [1-3]. These cellular functions are essential for preserving muscle strength and physical performance in adult life; interestingly, during the aging process these functions may decline dramatically leading to illness or disability in older adults.

Vitamin D deficiency in the older adult population has been related to chronic diseases such as frailty, sarcopenia, osteoporosis, mild cognitive impairment, dementia or type 2 diabetes mellitus (T2DM) [4-6]. The public health significance of the strong relationship 
between decreased serum 25-hydroxyvitamin D (25(OH)D) level and older population is as a risk factor for the onset of various chronic diseases. The prevalence of vitamin D deficiency worldwide is high; for example, in the adult population of the USA, its prevalence, adjusted for potential predictors as obesity, age and poor physical activity, is $28.9 \%$ [7]. In the European Union, the prevalence vitamin D deficiency is variable across countries between $13 \%$ and $40 \%$, considering age group, ethnic mix and latitude of the study population [8]. In Latin America, a deficiency of vitamin D has been reported in several countries [9]. In Mexico, for example, the prevalence of vitamin D deficiency was $62 \%$ in older adults influenced by factors such as gender, smoking habit, education and physical activity $[10,11]$. Growing scientific evidence has shown an important link between vitamin D deficiency and muscle health, especially in older adults. In this regard, a key problem is that the vitamin D cut-offs to determine deficiency or sufficiency of this hormone in older adults are not well defined and whether serum 25(OH)D level could be considered as a risk factor in the prognosis of chronic disease is not clear.

The variability in the serum 25(OH)D levels over the years could be the result of several factors such as nutritional status, the presence of intestinal or chronic kidney disease, or even life style. In clinical practice, specific cut-offs limits have been proposed for its use in older adults: deficiency $(<50 \mathrm{nmol} / \mathrm{L}(<20 \mathrm{ng} / \mathrm{mL}))$; insufficiency $(50-75 \mathrm{nmol} / \mathrm{L}$ $(20-30 \mathrm{ng} / \mathrm{mL}))$ and normal $(>75 \mathrm{nmol} / \mathrm{L}(>30 \mathrm{ng} / \mathrm{mL}))$. These vitamin D cut-off points are based on the serum parathyroid hormone levels and absorption of calcium from the gastrointestinal tract in the general population [12]. Additionally, different cutoff points have been associated to other conditions such as increased risk of fractures, falls, and myopathy in older people of Caucasian and Hispanic/Latino descent $[4,11,13-17]$, as well as infectious and cardiovascular diseases $[18,19]$. In particular, in a longitudinal study based on data from the NHANES, a cutoff level of $40 \mathrm{nmol} / \mathrm{L}[16 \mathrm{ng} / \mathrm{mL}]$ was set because this plasma concentration complies with an intake equivalent to the Estimated Average Requirement [20].

Aging is associated with a gradual and progressive impairment of the musculoskeletal function and, when the loss of muscle mass and strength leads to falls, functional deterioration and disability, in older people, the condition is known as sarcopenia. This clinical entity has a very complex pathophysiology [21], the cellular and physiological mechanisms involved in muscle function are distinct for the muscle mass and muscle strength components. These differences are important to accurately define the concept of dynapenia vs the more widely known concept of sarcopenia. The term of dynapenia is defined as an age-related loss of muscle strength (maximal voluntary force) and mechanical power (product of force times velocity) [22,23].

A large portion of vitamin D requirements is obtained through sunlight exposure in young people; but the supply of this vitamin is reduced in the old age due to an inadequate nutrition and the presence of chronic diseases [24,25]. A poor nutritional status is a frequent health problem found in older adults, and in some populations, it has been found in association with sarcopenia and dynapenia [26-28]. Furthermore, it is well known that an inadequate diet is a determinant factor in vitamin D deficiency [29]. In this regard, an instrument used extensively by specialists to assess the nutritional status of older adults is the Mini Nutritional Assessment (MNA) score. This tool has been previously used to assess the association of vitamin D levels with nutritional status in older adults. Low MNA scores were associated to an increased likelihood of having decreased level of serum vitamin D in very old adults [30]; likewise, Santos et al., reported that the risk of malnourishment and malnutrition increased the risk of vitamin D deficiency among adults over 65 years old, from Nutrition UP 62 study [31]. Furthermore, there are studies that estimate intake rather than measure vitamin D plasma levels in the geriatric population [32,33]. Similarly, in clinical practice the vitamin D status of patients is not assessed systematically.

A number of studies carried out in clinical facilities have shown an association between dynapenia and vitamin D deficiency, suggesting a relevant role for vitamin D in muscle function in older adults. Specifically, there are reports of patients with hip fractures [34,35], 
and in vulnerable groups such as immigrants or people with disabilities [36,37]. In contrast with the above, information on older adults living in their communities is scarce [38-40].

On the other hand, a dramatic worldwide increase in the prevalence of T2DM has been observed in association with skeletal muscle disorders in older adults [41,42]. In this regard, epidemiological studies have shown a high prevalence of sarcopenia in older adults presenting poor nutritional status and T2DM $[27,43,44]$.

Not enough epidemiological evidence is available in independent, community dwelling, older adults about the relationship between vitamin D levels, and muscle function, nutritional status and T2DM in Latin American populations, including Mexico. In this regard, it should be emphasized that ethnical background appears to play an important role in determining the circulating levels of vitamin D [20].

Thus, the main aim of the current study was to identify the association between handgrip strength, nutritional status, T2DM and vitamin D deficiency in Mexican, communitydwelling, older women.

\section{Materials and Methods}

\subsection{Study Design}

A cross-sectional study was performed in a group of elder women who attended a social and sports center located in the southeast area of Mexico City. At this facility, people exercise (dancing, swimming, yoga and tai chi) and engage in social gatherings. The study was conducted in strict adherence to the Helsinki principles for medical research in human subjects. The research protocol was approved by the National Geriatric Institute in Mexico City (DI-PI-009/2018) and the research was conducted from February 2019 to February 2020.

The goals and procedures of the study were explained individually to each invited older adult. Those willing to participate signed a consent letter where the risks and benefits of the study were clearly explained. All the participants received counseling based upon the results of their evaluations. To be included in the study, the following criteria had to be fulfilled by the interested person: 60 years of age and older, and physically able to walk by themselves. Individuals with severe illnesses or disability as well as those unwilling to participate were excluded from the study. The information about the presence of preexisting chronic diseases, was obtained during the survey by asking the participant women an open-ended question about concurrent health conditions.

\subsection{Sample Size}

Sample size calculation was performed with the aim of testing whether the odds ratio, $(\mathrm{OR})$, between two groups is different from the null value $(\mathrm{Ho}: \mathrm{OR}=1)$ [45]. A proportion of older adults with low plasma vitamin D level and low handgrip strength of 0.35 , and a proportion of 0.10 in the group without vitamin D deficiency was assumed. An $\alpha=0.05$ and a power (1- $\beta$ ) of 0.80 was used. The calculated sample size was 98 individuals; then, assuming a non-response rate of $25 \%$, a total of 123 individuals were sought to participate in the study. Of the total of 123 older women, five did not agree to take part in the study (response rate 95.9\%). Additionally, pre-existing medical conditions were recorded in each one of the 118 older women, but two of them were excluded from the study since they had a critical illness or disability. In the end, a data from a total of 116 older women were included in the analysis. Socio-demographic information for each participant was collected through a questionnaire.

\subsection{Nutritional Status}

To assess the nutritional status of each participant, the 18 -item version of the Mininutritional assessment (Full-MNA) tool, carrying a score ranging from 0-30, was used; after computing the scores, participant women were classified as malnourished (Full-MNA score $<17.0$ ), at risk of malnutrition (Full-MNA 17.0-23.5), and well-nourished (Full-MNA score $>23.5)[46,47]$. The anthropometric measurements were performed by a certified 
dietitian following standardized procedures [48-50]. Body mass index (BMI) was classified using the values suggested by the World Health Organization (WHO) [51]. Additionally, the Lipschitz criteria was applied in order to identify underweight women [52]. To assess the examiner's reliability, 15 (13\%) of the participants were evaluated in duplicate. The inter-examiner consistency of the anthropometric measurement results was $93 \%$.

\subsection{Handgrip Strength}

For handgrip strength assessment, a mechanical hand dynamometer was used (TKK 5001; Takei Scientific Instruments, Tokyo, Japan), the measurements were performed in triplicate for each participant; the average of the two highest values was subsequently obtained [53]. Low handgrip strength $(<16 \mathrm{Kg}$ for women) was defined according to the value proposed in the revised algorithm for sarcopenia diagnosis from the European Working Group on Sarcopenia in Older People (EWGSOP) [54].

\subsection{Activities of Daily Living}

For the assessment of the Activities of Daily Living (ADL) we used the Barthel Index (BI) score, which takes values in the range of 0 to 100 [55]. Based on this score, the participants were classified as follows: "Totally dependent" (BI $\leq 20$ points), "Severely dependent" (BI 21-60 points), "Moderately dependent" (BI 61-90 points), "Mildly dependent" (BI 91-99 points) or "Independent" (BI = 100 points).

\subsection{Biochemical Assessment of 25(OH)D}

Venous blood samples were drawn using a vacutainer blood collection system (BD Medical, New Jersey, USA), the blood cells were immediately separated by centrifugation, and the plasma was saved and stored at $-20^{\circ} \mathrm{C}$.

25-hydroxyvitamin D was determined by a quantitative immunoassay technique using a commercial kit as (Abcam ELISA kit number ab213966, Cambridge, MA, USA) per the provider instructions; the assay had a sensitivity of $4.94 \mathrm{nmol} / \mathrm{L}[1.98 \mathrm{ng} / \mathrm{mL}]$; the detection range was $1.25 \mathrm{nmol} / \mathrm{L}[0.5 \mathrm{ng} / \mathrm{mL}]$ to $2520.96 \mathrm{nmol} / \mathrm{L}[1010 \mathrm{ng} / \mathrm{mL}]$. Colorimetric detection was performed on a Multiskan ${ }^{\mathrm{TM}} \mathrm{GO}$ UV/Vis microplate spectrophotometer (Thermo Scientific, Waltham, MA, USA).

\subsection{Statistical Analysis}

Categorical variables are presented as percentages while numeric variables as means \pm standard deviations. The Pearson Chi -square test was used for testing independence between categorical variables. Comparison of means was performed using linear regression models.

To study the association between vitamin D status (cut off point $40 \mathrm{nmol} / \mathrm{L}$ [16 ng/mL]) and handgrip strength (cut off point $=16 \mathrm{~kg}$ ), MNA (cut off point $=23.5$ ), Barthel Index (cut off point $=100$ ) and T2DM logistic regression models were constructed, and crude and age adjusted OR were obtained, including confidence intervals $(95 \% \mathrm{CI})$. Interactions between nutritional status and handgrip strength were tested. To evaluate the goodness of fit of the models, we used the Hosmer-Lemeshow test. Statistical significance was set at $\alpha=0.05$. The statistical package STATA V 16 (College Station, TX, USA) was used for data analysis.

\section{Results}

In this study, 116 women over 65 years-old were included, the mean age was $70.3( \pm 5.8)$ year. Table 1 displays the demographic features of the study population, shows that less than a half of the participant women were married (44.8\%), while about a third of them were widows (32.8\%). Regarding the occurrence of chronic diseases, the most common condition was high blood pressure (HBP) $(44.0 \%)$, followed by T2DM which afflicted $17.2 \%$ of the study participants. The nutritional condition of the majority of the participants was normal $(76.7 \%)$, but about $23.1 \%$ was either at risk of developing malnutrition or malnourished. The handgrip strength average value was $18.1 \pm 4.0 ; 28.5 \%$ of participants 
in the study group had decreased handgrip strength $(<16 \mathrm{~kg})$. The results from the Barthel index assessments indicated that the majority of these older women were independent enough to carry out basic activities of daily living (68.1\%) (Table 1). Bladder incontinence was the most common disorder found among the study participants accounting for $19.8 \%$ of all. Less than $5 \%$ of the participants had trouble walking, moving from their bed to a chair, climbing stair or bowel continence. Only one participant $(0.9 \%)$ reported some degree of dependency for activities such as feeding, bathing, dressing, grooming, or toilet use. On the other hand, the participants had a mean plasma level of $25(\mathrm{OH}) \mathrm{D}$ was $58.4 \pm 90.8 \mathrm{nmol} / \mathrm{L}(23.4 \pm 36.38 \mathrm{ng} / \mathrm{mL})$, however, values under $50 \mathrm{nmol} / \mathrm{L}(20 \mathrm{ng} / \mathrm{mL})$ and $40 \mathrm{nmol} / \mathrm{L}(16 \mathrm{ng} / \mathrm{mL})$ were observed in $60.3 \%$ and $49.1 \%$ of them, respectively. Only $16.4 \%$ of the participants had levels of $25(\mathrm{OH}) \mathrm{D}$ above $75 \mathrm{nmol} / \mathrm{L}(>30 \mathrm{ng} / \mathrm{mL}$ ). No significant difference $(\mathrm{p}=0.567)$ was found in the mean plasma concentrations of $25(\mathrm{OH}) \mathrm{D}$ between the group of 32 participants studied during the period Spring-Summer (mean $70.57 \pm 134.9 \mathrm{nmol} / \mathrm{L}(28.27 \pm 54 \mathrm{ng} / \mathrm{mL}))$ compared to the 84 participants studied during Fall-Winter $(53.7 \pm 67.5 \mathrm{nmol} / \mathrm{L}(21.52 \pm 27 \mathrm{ng} / \mathrm{mL}))$ period.

Table 1. Sociodemographic characteristics, medical conditions, nutritional status, activities of daily living score, and plasma 25(OH)D concentration of community dwelling Mexican older women.

\begin{tabular}{|c|c|c|}
\hline Characteristic & $n=116$ & \\
\hline \multirow[t]{2}{*}{ Age (years) mean \pm sd } & $70.3 \pm 5.8$ & \\
\hline & $\mathrm{n}$ & $(\%)$ \\
\hline $60-64$ & 12 & $(10.3)$ \\
\hline $65-74$ & 79 & $(68.1)$ \\
\hline$\geq 75$ & 25 & $(21.5)$ \\
\hline \multicolumn{3}{|l|}{ Marital status } \\
\hline Married & 52 & $(44.8)$ \\
\hline Widowed & 38 & (32.8) \\
\hline Non-married / never married & 26 & $(22.4)$ \\
\hline \multicolumn{3}{|l|}{ Chronic diseases } \\
\hline Hypertension & 51 & $(44.0)$ \\
\hline Diabetes & 20 & $(17.2)$ \\
\hline Cardiovascular disease & 8 & $(6.9)$ \\
\hline Osteoporosis & 27 & (23.3) \\
\hline Osteoarthritis & 16 & (13.8) \\
\hline Thyroid diseases & 10 & $(8.6)$ \\
\hline Depression & 15 & $(12.9)$ \\
\hline Dementia & 1 & $(0.9)$ \\
\hline Recent fracture & 10 & $(8.6)$ \\
\hline Autoimmune disease & 8 & $(6.9)$ \\
\hline Others & 9 & $(7.8)$ \\
\hline \multicolumn{3}{|l|}{ Nutritional Status } \\
\hline Full-MNA (points), mean \pm sd & $25.4 \pm 3.0$ & \\
\hline Well-nourished & 89 & $(76.7)$ \\
\hline At risk of malnutrition & 25 & $(21.6)$ \\
\hline Malnourished & 2 & $(1.7)$ \\
\hline \multicolumn{3}{|l|}{ Handgrip strength } \\
\hline Handgrip strength $(\mathrm{kg})$, mean $\pm \mathrm{sd}$ & $18.1 \pm 4.0$ & \\
\hline$<16 \mathrm{~kg}$ & 33 & $(28.5)$ \\
\hline$\geq 16 \mathrm{~kg}$ & 83 & (71.5) \\
\hline \multicolumn{3}{|l|}{ Activities of daily living } \\
\hline Barthel Index (points), mean \pm sd & $97.9 \pm 4.2$ & \\
\hline Independent & 82 & $(70.7)$ \\
\hline Midly dependent & 24 & (20.7) \\
\hline Moderately dependent & 10 & $(8.6)$ \\
\hline Severely dependent & 0 & $(0.0)$ \\
\hline Totally dependent & 0 & $(0.0)$ \\
\hline \multicolumn{3}{|l|}{ Vitamin D } \\
\hline Plasma concentration $25(\mathrm{OH}) \mathrm{D}$ nmol $/ \mathrm{L}$, mean $\pm \mathrm{sd}$ & $58.4 \pm 90.8$ & \\
\hline Plasma concentration $25(\mathrm{OH}) \mathrm{D} n g / \mathrm{mL}$, mean $\pm \mathrm{sd}$ & $23.38 \pm 36.4$ & \\
\hline $25(\mathrm{OH}) \mathrm{D}<40 \mathrm{nmol} / \mathrm{L}(<16 \mathrm{ng} / \mathrm{mL})$ & 57 & $(49.14)$ \\
\hline $25(\mathrm{OH}) \mathrm{D} \geq 40 \mathrm{nmol} / \mathrm{L}(\geq 16 \mathrm{ng} / \mathrm{mL})$ & 59 & $(50.86)$ \\
\hline
\end{tabular}

Table 2 shows the anthropometric characteristics of the study group. It shows that $30.2 \%$ of the study participants had a normal Body Mass Index (BMI) according to the 
WHO cut-offs points. However, using the Lipschitz criteria up to $46.1 \%$ of the participants were overweight, and only $10.4 \%$ were underweight.

Table 2. Anthropometric characteristics of community dwelling Mexican older women.

\begin{tabular}{cc}
\hline Measurements & Total \\
\cline { 2 - 2 } & $\boldsymbol{n = 1 1 6}$ \\
\hline Weight $(\mathrm{kg})$ mean $\pm \mathrm{sd}$ & $61.6 \pm 10.7$ \\
Height $(\mathrm{cm})$ mean $\pm \mathrm{sd}$ & $150.9 \pm 6.6$ \\
Body Mass Index $\left(\mathrm{kg} / \mathrm{m}^{2}\right)$ mean $\pm \mathrm{sd}$ & $27.1 \pm 4.3$ \\
WHO classification & \\
Normal $n(\%)$ & $35(30.2)$ \\
Overweight $n(\%)$ & $57(49.1)$ \\
Obesity $n(\%)$ & $24(20.7)$ \\
Lipschitz classification & $12(10.4)$ \\
Underweight $n(\%)$ & $50(43.5)$ \\
Normal $n(\%)$ & $53(46.1)$ \\
Overweight $n(\%)$ & $30.0 \pm 3.5$ \\
Mid-upper arm circumference $(\mathrm{cm})$ mean $\pm \mathrm{sd}$ & $34.5 \pm 3.2$ \\
Calf circumference $(\mathrm{cm})$ mean $\pm \mathrm{sd}$ &
\end{tabular}

WHO, World Health Organization.

The distribution of anthropometric variables, handgrip strength, Full-MNA and Barthel index with plasma level values of $25(\mathrm{OH}) \mathrm{D}$ above and below a cut-off point of $40 \mathrm{nmol} / \mathrm{L}(16 \mathrm{ng} / \mathrm{mL})$ are shown in Table 3 . None of the features shown was associated with the plasma levels of $25(\mathrm{OH}) \mathrm{D}(p=0.393)$ except for two: handgrip strength $(p=0.014)$, and Full-MNA score $(p=0.002)$. No association between the mean score of basic activities of daily living (Barthel index) and 25(OH)D was observed $(p=0.498)$.

Table 3. Anthropometric measurements, handgrip strength, MNA, and Barthel Index according to plasma 25(OH)D concentration in community dwelling Mexican older women.

\begin{tabular}{|c|c|c|c|}
\hline \multirow{3}{*}{ Variable } & \multicolumn{3}{|c|}{ Plasmatic Vitamin 25(OH)D Status } \\
\hline & \multirow{2}{*}{$\begin{array}{c}\text { Vit } \mathrm{D}<40 \mathrm{nmol} / \mathrm{L}[16 \mathrm{ng} / \mathrm{mL}] \\
n=57\end{array}$} & \multirow{2}{*}{$\begin{array}{c}\text { Vit } \mathrm{D} \geq 40 \mathrm{nmol} / \mathrm{L}[16 \mathrm{ng} / \mathrm{mL}] \\
n=59\end{array}$} & \multirow{2}{*}{$p$} \\
\hline & & & \\
\hline Age (years), mean $\pm S D$ & $70.72 \pm 6.51$ & $69.80 \pm 5.02$ & 0.393 \\
\hline Weight $(\mathrm{kg})$, mean $\pm \mathrm{SD}$ & $61.80 \pm 11.78$ & $61.49 \pm 9.69$ & 0.877 \\
\hline Height $(\mathrm{cm})$, mean \pm SD & $150.63 \pm 6.54$ & $151.08 \pm 6.65$ & 0.716 \\
\hline Body Mass Index $\left(\mathrm{kg} / \mathrm{m}^{2}\right)$, mean $\pm \mathrm{SD}$ & $27.17 \pm 4.57$ & $26.95 \pm 4.07$ & 0.787 \\
\hline $\begin{array}{l}\text { Mid-upper-arm circumference }(\mathrm{cm}) \\
\text { mean } \pm \mathrm{SD}\end{array}$ & $30.14 \pm 3.95$ & $29.84 \pm 3.13$ & 0.656 \\
\hline Calf circumference $(\mathrm{cm})$, mean $\pm S D$ & $34.19 \pm 3.45$ & $34.81 \pm 3.01$ & 0.304 \\
\hline Hand grip strength $(\mathrm{kg})$, mean $\pm \mathrm{SD}$ & $17.19 \pm 4.03$ & $18.99 \pm 3.75$ & 0.014 \\
\hline Full-MNA (score), mean \pm SD & $24.51 \pm 3.07$ & $26.25 \pm 2.71$ & 0.002 \\
\hline Barthel Index (score), mean \pm SD & $97.45 \pm 3.91$ & $97.96 \pm 4.16$ & 0.498 \\
\hline
\end{tabular}

Table 4 shows the association between plasma levels of $25(\mathrm{OH}) \mathrm{D}$ and age, presence of T2DM, handgrip strength, nutritional status, and Barthel index score. These results showed that a high proportion of women with T2DM also have low levels of 25(OH)D compared to those who do not have the disease equally low levels of 25(OH)D $(p=0.040)$. Women with low handgrip strength $(<16 \mathrm{Kg})$ showed lower levels of $25(\mathrm{OH}) \mathrm{D}$ more often than those with higher handgrip strength $(p=0.017)$. Importantly, women at risk of malnutrition or malnourished also had lower plasma $25(\mathrm{OH}) \mathrm{D}(p=0.038)$. In contrast with the above results, Barthel index was not associated with 25(OH)D levels. 
Table 4. Age, handgrip strength, MNA according to plasma 25(OH)D concentration in community dwelling Mexican older women.

\begin{tabular}{|c|c|c|c|c|}
\hline \multirow[b]{2}{*}{ Variable } & \multicolumn{2}{|c|}{ Plasmatic Vitamin 25(OH)D Status } & \multirow[b]{2}{*}{$\begin{array}{c}\text { Total } \\
n \\
(\text { Column \%) }\end{array}$} & \multirow[b]{2}{*}{$p$} \\
\hline & $\begin{array}{c}\text { Vit } \mathrm{D}<40 \mathrm{nmol} / \mathrm{L} \\
{[16 \mathrm{ng} / \mathrm{mL}]} \\
n=57 \\
n(\text { Row } \%)\end{array}$ & $\begin{array}{c}\text { Vit } \mathrm{D} \geq 40 \mathrm{nmol} / \mathrm{L} \\
{[16 \mathrm{ng} / \mathrm{mL}]} \\
n=59 \\
n(\text { Row } \%)\end{array}$ & & \\
\hline \multicolumn{5}{|l|}{ Age } \\
\hline$\geq 70$ years & $25(43.86)$ & $32(56.14)$ & $57(49.14)$ & \multirow[t]{2}{*}{0.264} \\
\hline$<70$ years & $32(54.24)$ & $27(45.76)$ & $59(50.86)$ & \\
\hline \multicolumn{5}{|l|}{ T2DM } \\
\hline Yes & $14(89.83)$ & $6(10.17)$ & $20(17.24)$ & \multirow[t]{2}{*}{0.040} \\
\hline No & $43(75.44)$ & $53(24.56)$ & $96(82.76)$ & \\
\hline \multicolumn{5}{|l|}{ Hand grip strength } \\
\hline$<16 \mathrm{~kg}$ & $22(66.67)$ & $11(33.33)$ & $33(28.45)$ & \multirow[t]{2}{*}{0.017} \\
\hline$\geq 16 \mathrm{~kg}$ & $35(42.17)$ & $48(57.83)$ & $83(71.55)$ & \\
\hline \multicolumn{5}{|l|}{ Activities of daily living } \\
\hline Mildly/moderately dependent & $20(58.82)$ & $14(41.18)$ & $34(29.31)$ & \multirow[t]{2}{*}{0.179} \\
\hline Independent & $37(45.12)$ & $45(54.88)$ & $82(70.69)$ & \\
\hline \multicolumn{5}{|l|}{ Full - Mini Nutritional Assessment } \\
\hline Risk/Malnourished & $18(66.67)$ & $9(33.33)$ & $27(23.28)$ & \multirow[t]{2}{*}{0.038} \\
\hline Normal & $39(43.82)$ & $50(56.18)$ & $89(76.72)$ & \\
\hline
\end{tabular}

Along the same lines of data shown above, in Table 5, OR results from the logistic regression adjusted model indicated an association between T2DM and vitamin D deficiency in the participant women. In fact, women with the disease are 3 times as likely of having low levels of 25(OH)D than women without T2DM (OR $=2.92, p=0.044)$. Similarly, older women with vitamin $\mathrm{D}$ deficiency were more than twice as likely of having low handgrip strength as those with higher vitamin $\mathrm{D}$ values $(\mathrm{OR}=2.64, p=0.025)$. Furthermore, the risk of malnutrition or frank malnutrition was associated to a higher probability of having lower levels of circulating $25(\mathrm{OH}) \mathrm{D}(\mathrm{OR}=2.53, p=0.045)$, no significant association was found between vitamin D status and Barthel Index $(p=0.258)$. Lastly, no statistically significant interaction was observed between nutritional status and the decrease of handgrip strength as a function of vitamin D deficiency $(p>0.05)$.

Table 5. Crude and adjusted logistic regression OR of handgrip strength and nutritional status, type 2 diabetes mellitus, and plasma 25(OH)D concentration in community dwelling Mexican older women.

\begin{tabular}{ccccccc}
\hline Variable & OR Crude & OR 95\% CI & $p$ & $\begin{array}{c}\text { OR } \\
\text { Adjusted * }\end{array}$ & OR 95\% CI & $p$ \\
\hline Hand grip strength & 2.74 & $1.18-6.38$ & 0.019 & 2.64 & $1.13-6.18$ & 0.025 \\
Full-MNA & 2.56 & $1.04-6.33$ & 0.041 & 2.53 & $1.02-6.26$ & 0.045 \\
$\begin{array}{c}\text { Activities of } \\
\text { daily living }\end{array}$ & 1.74 & $0.77-3.91$ & 0.181 & 1.61 & $0.70-3.69$ & 0.258 \\
T2DM & 2.88 & $1.02-8.12$ & 0.046 & 2.92 & $1.03-8.31$ & 0.044 \\
\hline
\end{tabular}

*OR adjusted by age. Cut off values of independent variables: age $=70$ years, hand grip strength $=16 \mathrm{~kg}$, FullMNA score $=23.5$, Barthel Index score $=100.25(\mathrm{OH}) \mathrm{D}$ OR reference value $25(\mathrm{OH}) \mathrm{D} \geq 40 \mathrm{nmol} / \mathrm{L}(16 \mathrm{ng} / \mathrm{mL})$.

\section{Discussion}

In this study an association between low circulating levels of vitamin $\mathrm{D}$, under $40 \mathrm{nmol} / \mathrm{L}$ (16 ng/mL), and decreased handgrip strength was found in Mexican older women engaged in social and recreational activities. In agreement with our results, a U.S. study on a group of people 98 years of age and older, community dwelling or living in nursing homes, were studied found that plasma levels of $25(\mathrm{OH}) \mathrm{D}$ lower than $75 \mathrm{nmol} / \mathrm{L}$ (30 ng/mL) were associated with lower handgrip strength [56]. It is conceivable that the mechanisms underlying this association have to do with the known role of $25(\mathrm{OH}) \mathrm{D}$ or its 
metabolites in the regulation of genes and signaling pathways involved in calcium and phosphate homeostasis, as well as the proliferation and differentiation of skeletal muscle cells $[57,58]$. Vitamin D controls the initiation of muscular regeneration by promoting an increase of the cross-sectional area of skeletal muscle fibers through modulatory actions on the cell cycle of the skeletal tissue [59-61].

Numerous epidemiological studies have suggested a potential role for vitamin $\mathrm{D}$ in the maintenance of skeletal muscle function, physical performance, and the preservation of independence in older adults [62,63]. In this regard, several randomized clinical assays have examined the link between vitamin D supplementation and improved muscular strength. For example, a study on a cohort of 65 years-old patients with knee osteoarthritis, a significant improvement in grip strength and physical performance was observed with vitamin D supplementation, even though it did not improve knee extension [64]. Another study in Australia found that the strength of the hip muscles improved significantly after vitamin $\mathrm{D}_{2}$ supplementation with a $1000 \mathrm{IU} /$ day dose during one year in older women with vitamin D deficiency [65]. Despite these findings, results from a meta-analysis in community dwelling people over 65 years-old, did not find any improvement of muscular strength after vitamin D and calcium supplementation [66].

The results showed that nearly one half of the population studied have low levels of vitamin $\mathrm{D}(<40 \mathrm{nmol} / \mathrm{L}(16 \mathrm{ng} / \mathrm{mL}))$, in agreement with previous studies in Mexicans [10]. The mean plasma vitamin $\mathrm{D}$ value found in the current study was closely similar to that reported by the Mexican Health and Aging Study (2012) in women over 60-years old [11]. Interestingly, the vitamin D levels in this study were lower than those determined in samples of the population also over 60 years old but living in the southern states of Mexico [67]. It is possible that this is due to a higher sun exposure in communities in the south part of Mexico which are much less urbanized than Mexico City, and possibly also to differences of lifestyle. A study performed in the United States about the trends of vitamin D concentrations showed that non-Hispanic Whites but not Hispanics and Blacks-showed a slight trend towards an increase in vitamin D levels from the year 1998 to 2010; however, Mexican-Americans in this study did not show this variation [20]. Studies in Latin-American countries other than Mexico, have shown a deficiency of vitamin D in the adult population [9]. In a meta-analysis of data from various European countries reported various degrees of vitamin D deficiency [8]. These results suggest that deficiency of vitamin $\mathrm{D}$ is a prevalent problem in the older population of various regions of the world. Indeed, the oldest members of the population are at increased risk of developing vitamin D deficiency due to various causes including diminished skin synthesis secondary to limited sun exposure, chronic kidney disease (CKD) and malabsorption of the gastrointestinal tract $[59,68]$. Furthermore, there are reports of an aging associated decrease in the number of vitamin D receptors in skeletal muscle [69-71].

In the current study, we did not find seasonal differences in the levels of vitamin D throughout the year, which can be explained by the fact that Mexico City does not undergo major changes in the light/dark cycle as is the case in other world latitudes. This means that outdoors activity time in these populations is not subjected to marked variations. Several published studies have focused on geographic latitude as a modifying factor of vitamin D levels [72,73].

The results of the regression model in this study showed that women at risk of malnutrition or malnourished were more likely to have lower levels of vitamin D than were women with an adequate nutrition as assessed through the MNA. This nutrition evaluation tool not only has been validated and standardized in numerous human populations and allows to assess the nutritional status of older adults with various medical conditions [74]. Its full version, consisting of 18 items, includes four areas: anthropometric, general assessment, dietary assessment, and self-assessment [46].

In this regard, a study by Tsagari et al., demonstrated a correlation between MNA score and the plasma levels of vitamin D (rho $=0.685, p<0.001)$, suggesting that this score could be used as a reliable surrogate marker for vitamin D levels [75]. In another 
study performed in a group of Spanish adults over 85 years old, the authors found that lower MNA scores were associated to a higher probability of having a low circulating concentration of vitamin D $(<62.4 \mathrm{nmol} / \mathrm{L}(<25 \mathrm{ng} / \mathrm{mL}))$ [30]. Similarly, in a group of Portuguese adults over 65 years old, was reported that participants classified either at risk of malnutrition or as malnourished based on the MNA score, also had an increased risk of vitamin D deficiency $(<30 \mathrm{nmol} / \mathrm{L}(<12 \mathrm{ng} / \mathrm{mL}))$ when compared to participants in good nutritional condition [31]. When comparing these results with those of the current study, we have to bear in mind the heterogeneity of the various studies, especially regarding the cut off points for vitamin D levels, as well as the specific features of the subjects of study. Despite all this, the association between nutritional status (MNA score) and the deficiency of vitamin D appears to be consistent.

Dietary patterns could account for the association between nutritional status and vitamin D. For example, in a cross-sectional study the researchers observed that meat and fish consumers showed a higher level of vitamin D compared to vegetarian and vegan persons [76]. It has also been reported that among adults over 65 years-old high MNA scores are associated to the habit of consuming higher amounts of white meat, red meat and processed meat [77]. Despite the fact that daily intake in the diet is not the only determinant of the plasma levels vitamin $\mathrm{D}$, a cross-sectional study by Nakamura et al. showed that the intake of meals rich in the vitamin (such as fish) may play a role in the maintenance of adequate vitamin $\mathrm{D}$ levels in the long term [78]. The current results suggest that the circulating levels of vitamin D should be taken into account in the assessment of the nutritional status of older adults, in light of the observation that patients with normal MNA scores may have low vitamin D levels, as reported in a population of Spanish older people by Formiga et al. [30] and in the current study.

Our findings contribute to strengthen the concept that low levels of vitamin D are associated with the presence of T2DM. Furthermore, these results confirm this observation reported in only a handful of previous studies on similar cohorts of human subjects [79-81]. So far, the mechanisms underlying the association between vitamin D deficiency and T2DM have remained elusive due probably to the fact that most studies in the literature are descriptive in nature and have not focused on investigating the cause-effect relationships between vitamin D supplementation and the development of T2DM [82-84].

In vitro studies have shown that beta cells from human pancreatic islets of subjects with vitamin D deficiency are insulin resistant, thus directly linking the two phenomena [85]. Interestingly, it has been reported that rat pancreatic islets express both the mRNA and the protein of 1-alpha-hydroxylase (CYP27B1), an enzyme involved in the conversion of the inactive to the active form of vitamin D [86]. Additionally, in vivo studies have shown that vitamin $\mathrm{D}$ deficient rats displayed a phenotype characterized by decreased insulin secretion, a defect that is corrected after vitamin D supplementation [87]. Altogether, these studies provide clues about the possible mechanisms underlying the improvement of insulin sensitivity observed after supplementation with vitamin $\mathrm{D}$, and may suggest a role of this defect in the pathophysiology of T2DM.

One limitation of the current study is that its cross-sectional design did not allow us to identify a cause-effect relationship. Furthermore, the number of participants in the study was small; notwithstanding the above, it was possible to establish associations regarding relevant aging markers such as handgrip strength and nutritional status.

\section{Conclusions}

This study confirms and extends the evidence indicating that vitamin D deficiency entails negative consequences on handgrip strength even in independent older women. This study found a relationship between a low circulating level of vitamin D and a decrease of handgrip strength, and higher risk of malnutrition. Similarly, women with T2DM had lower levels of vitamin D compared to their non-diabetic counterparts. 
Author Contributions: Conceptualization, L.M.-G., M.C.V.-A., I.A.-C. and M.E.I.-C.; data curation, L.M.-G., M.C.V.-A., M.F.C.-R., I.A.-C. and M.E.I.-C.; formal analysis, L.M.-G., M.C.V.-A., I.A.-C., R.G.-J. and M.E.I.-C.; funding acquisition, L.M.-G., M.C.V.-A. and I.A.-C.; investigation, L.M.-G., M.C.V.-A., M.F.C.-R., I.A.-C. and M.E.I.-C.; methodology, L.M.-G., M.C.V.-A., M.F.C.-R., I.A.-C., R.G.-J. and M.E.I.-C.; resources, L.M.-G., M.C.V.-A., I.A.-C. and M.E.I.-C.; software, L.M.-G., M.C.V.-A., M.F.C.-R., I.A.-C., R.G.-J. and M.E.I.-C; supervision, L.M.-G., M.C.V.-A. and I.A.-C.; writing-original draft, L.M.-G., M.C.V.-A., M.F.C.-R., I.A.-C., R.G.-J. and M.E.I.-C.; writing-review and editing, L.M.-G., M.C.V.-A., M.F.C.-R., I.A.-C., R.G.-J. and M.E.I.-C. All authors have read and agreed to the published version of the manuscript.

Funding: This research was funded in part by National Council of Science and Technology from Mexico, grant number: FOSISS-SALUD-2018-01-A3-S-37938 to L.M.-G.

Institutional Review Board Statement: The study was conducted according to the guidelines of the Declaration of Helsinki, and approved by the Institutional Review Board of National Institute of Geriatrics (DI-PI-009/2018, date of approval 26 November 2018).

Informed Consent Statement: Informed consent was obtained from all subjects involved in the study.

Data Availability Statement: The data presented in this study are available on request from the corresponding author. Some data are not publicly available due to participants' confidentiality agreement.

Acknowledgments: The authors thank to Itzam Rangel from the Metropolitan Autonomous University and Raúl Alejandro Librado-Osorio from the National Institute of Geriatrics (Mexico) for their expert technical assistance.

Conflicts of Interest: The authors declare no conflict of interest.

\section{References}

1. Saponaro, F.; Saba, A.; Zucchi, R. An update on vitamin D metabolism. Int. J. Mol. Sci. 2020, 21, 6573. [CrossRef] [PubMed]

2. Rybchyn, M.S.; Abboud, M.; Puglisi, D.A.; Gordon-Thomson, C.; Brennan-Speranza, T.C.; Mason, R.S.; Fraser, D.R. Skeletal muscle and the maintenance of vitamin D status. Nutrients 2020, 12, 3270. [CrossRef]

3. Christakos, S.; Dhawan, P.; Verstuyf, A.; Verlinden, L.; Carmeliet, G. Vitamin D: Metabolism, molecular mechanism of action, and pleiotropic effects. Physiol. Rev. 2016, 96, 365-408. [CrossRef]

4. D'Amelio, P.; Quacquarelli, L. Hypovitaminosis D and aging: Is there a role in muscle and brain health? Nutrients 2020, 12. [CrossRef]

5. Lozano, M.; Manyes, L.; Peiró, J.; Ramada, J.M. Nutrients associated with diseases related to aging: A new healthy aging diet index for elderly population. Nutr. Hosp. 2018, 35, 1287-1297. [CrossRef]

6. Pittas, A.G.; Dawson-Hughes, B.; Sheehan, P.; Ware, J.H.; Knowler, W.C.; Aroda, V.R.; Brodsky, I.; Ceglia, L.; Chadha, C.; Chatterjee, R.; et al. Vitamin D supplementation and prevention of type 2 diabetes. N. Engl. J. Med. 2019, 381, 520-530. [CrossRef] [PubMed]

7. Liu, X.; Baylin, A.; Levy, P.D. Vitamin D deficiency and insufficiency among US adults: Prevalence, predictors and clinical implications. Br. J. Nutr. 2018, 119, 928-936. [CrossRef]

8. Cashman, K.D.; Dowling, K.G.; Škrabáková, Z.; Gonzalez-Gross, M.; Valtueña, J.; de Henauw, S.; Moreno, L.; Damsgaard, C.T.; Michaelsen, K.F.; Mølgaard, C.; et al. Vitamin D deficiency in Europe: Pandemic? Am. J. Clin. Nutr. 2016, 103, $1033-1044$. [CrossRef] [PubMed]

9. Brito, A.; Cori, H.; Olivares, M.; Mujica, M.F.; Cediel, G.; López de Romaña, D. Less than adequate vitamin D status and intake in latin america and the caribbean: A problem of unknown magnitude. Food Nutr. Bull. 2013, 34, 52-64. [CrossRef]

10. Martínez-Zavala, N.; López-Sánchez, G.N.; Vergara-Lopez, A.; Chávez-Tapia, N.C.; Uribe, M.; Nuño-Lámbarri, N. Vitamin D deficiency in mexicans have a high prevalence: A cross-sectional analysis of the patients from the centro médico nacional 20 de noviembre. Arch. Osteoporos. 2020, 15, 1-5. [CrossRef] [PubMed]

11. Carrillo-Vega, M.F.; García-Peña, C.; Gutiérrez-Robledo, L.M.; Pérez-Zepeda, M.U. Vitamin D deficiency in older adults and its associated factors: A cross-sectional analysis of the mexican health and aging study. Arch. Osteoporos. 2017, 12. [CrossRef]

12. Holick, M.F. Vitamin D deficiency. N. Engl. J. Med. 2007, 357, 266-281. [CrossRef]

13. Valcour, A.; Blocki, F.; Hawkins, D.M.; Rao, S.D. Effects of age and serum 25-OH-Vitamin D on serum parathyroid hormone levels. J. Clin. Endocrinol. Metab. 2012, 97, 3989-3995. [CrossRef]

14. Bhattoa, H.P.; Konstantynowicz, J.; Laszcz, N.; Wojcik, M.; Pludowski, P. Vitamin D: Musculoskeletal health. Rev. Endocr. Metab. Disord. 2017, 18, 363-371. [CrossRef] [PubMed]

15. de La Cruz-Góngora, V.; Salinas-Rodríguez, A.; Villalpando, S.; Flores-Aldana, M. Serum retinol but not 25(OH)D status is associated with serum hepcidin levels in older mexican adults. Nutrients 2019, 11, 988. [CrossRef] 
16. Rivera-Paredez, B.; Macías, N.; Martínez-Aguilar, M.M.; Hidalgo-Bravo, A.; Flores, M.; Quezada-Sánchez, A.D.; DenovaGutiérrez, E.; Cid, M.; Martínez-Hernández, A.; Orozco, L.; et al. Association between Vitamin D deficiency and single nucleotide polymorphisms in the Vitamin D receptor and GC genes and analysis of their distribution in mexican postmenopausal women. Nutrients 2018, 10, 1175. [CrossRef] [PubMed]

17. Durazo-Arvizu, R.A.; Pacheco-Dominguez, R.L.; Sempos, C.T.; Kramer, H.; Hoofnagle, A.N.; Pirzada, A.; Cooper, R.S.; Daviglus, M.L. The association between cardiovascular disease risk factors and 25-hydroxivitamin d and related analytes among Hispanic/Latino Adults: A pilot study. Nutrients 2019, 11, 1959. [CrossRef]

18. Naesgaard, P.A.; León de la Fuente, R.A.; Nilsen, S.T.; Pönitz, V.; Brügger-Andersen, T.; Grundt, H.; Staines, H.; Nilsen, D.W.T. Suggested cut-off values for vitamin $\mathrm{D}$ as a risk marker for total and cardiac death in patients with suspected acute coronary syndrome. Front. Cardiovasc. Med. 2016, 3. [CrossRef]

19. Arnljots, R.; Snaebjörnsson Arnljots, E.; Thorn, J.; Elm, M.; Moore, M.; Sundvall, P.D. Bacteriuria and Vitamin D deficiency: A cross sectional study of 385 nursing home residents. BMC Geriatr. 2019, 19. [CrossRef] [PubMed]

20. Schleicher, R.L.; Sternberg, M.R.; Lacher, D.A.; Sempos, C.T.; Looker, A.C.; Durazo-Arvizu, R.A.; Yetley, E.A.; Chaudhary-Webb, M.; Maw, K.L.; Pfeiffer, C.M.; et al. The Vitamin D status of the US population from 1988 to 2010 using standardized serum concentrations of 25-hydroxyvitamin D shows recent modest increases. Am. J. Clin. Nutr. 2016, 104, 454-461. [CrossRef] [PubMed]

21. Morley, J.E.; Anker, S.D.; von Haehling, S. Prevalence, incidence, and clinical impact of sarcopenia: Facts, numbers, and epidemiology-Update 2014. J. Cachexia Sarcopenia Muscle 2014, 5, 253-259. [CrossRef] [PubMed]

22. Clark, B.C.; Manini, T.M. What is dynapenia? Nutrition 2012, 28, 495-503. [CrossRef] [PubMed]

23. Clark, B.C.; Manini, T.M. Sarcopenia $\neq$ Dynapenia. J. Gerontol. Med. Sci. 2008, 63, 829-834. [CrossRef]

24. Cashman, K.D.; Hill, T.R.; Lucey, A.J.; Taylor, N.; Seamans, K.M.; Muldowney, S.; FitzGerald, A.P.; Flynn, A.; Barnes, M.S.; Horigan, G.; et al. Estimation of the dietary requirement for vitamin d in healthy adults. Am. J. Clin. Nutr. 2008, 88, 1535-1542. [CrossRef] [PubMed]

25. Maclaughlin, J.; Holick, M.F. Aging decreases the capacity of human skin to produce vitamin D3. J. Clin. Investig. 1985, 76, 1536-1538. [CrossRef]

26. da Alexandre, T.S.; de Duarte, Y.A.O.; Santos, J.L.F.; Lebrão, M.L. Prevalence and associated factors of sarcopenia, dynapenia, and sarcodynapenia in community-dwelling elderly in São Paulo-SABE Study. Rev. Bras. Epidemiol. 2018, 21. [CrossRef]

27. Velázquez-Alva, M.C.; Irigoyen-Camacho, M.E.; Zepeda-Zepeda, M.A.; Lazarevich, I.; Arrieta-Cruz, I.; D’Hyver, C. Sarcopenia, nutritional status and type 2 diabetes mellitus: A cross-sectional study in a group of mexican women residing in a nursing home. Nutr. Diet. 2019. [CrossRef]

28. Neves, T.; Ferriolli, E.; Martin Lopes, M.B.; Crespilho Souza, M.G.; Fett, C.A.; Rezende Fett, W.C. Prevalence and factors associated with sarcopenia and dynapenia in elderly people. J. Frailty Sarcopenia Falls 2018, 3, 194-202. [CrossRef]

29. Denova-Gutiérrez, E.; Clark, P.; Muñoz-Aguirre, P.; Flores, M.; Talavera, J.O.; Gabriela Chico-Barba, L.; Rivas, R.; Ramírez, P.; Salmerón, J. Dietary patterns are associated with calcium and Vitamin D intake in an adult mexican population. Nutr. Hosp. 2016, 33, 663-670.

30. Formiga, F.; Ferrer, A.; Almeda, J.; San Jose, A.; Gil, A.; Pujol, R. Utility of geriatric assessment tools to identify 85 years old subjects with Vitamin D deficiency. J. Nutr. Health Aging 2011, 15, 110-114. [CrossRef] [PubMed]

31. Santos, A.; Amaral, T.F.; Guerra, R.S.; Sousa, A.S.; Álvares, L.; Moreira, P.; Padrão, P.; Afonso, C.; Borges, N. Vitamin D Status and associated factors among portuguese older adults: Results from the Nutrition UP 65 cross-sectional study. BMJ Open $2017,7$. [CrossRef] [PubMed]

32. Murphy, M.C.; Brooks, C.N.; New, S.A.; Lumbers, M.L. The use of the mini-nutritional assessment (MNA) tool in elderly orthopaedic patients. Eur. J. Clin. Nutr. 2000, 54, 555-562. [CrossRef]

33. Wojzischke, J.; van Wijngaarden, J.; van den Berg, C.; Cetinyurek-Yavuz, A.; Diekmann, R.; Luiking, Y.; Bauer, J. Nutritional status and functionality in geriatric rehabilitation patients: A systematic review and meta-analysis. Eur. Geriatr. Med. 2020, 11, 195-207. [CrossRef]

34. Gumieiro, D.N.; Murino Rafacho, B.P.; Buzati Pereira, B.L.; Cavallari, K.A.; Tanni, S.E.; Azevedo, P.S.; Polegato, B.F.; Mamede Zornoff, L.A.; Dinhane, D.I.; Innocenti Dinhane, K.G.; et al. Vitamin D serum levels are associated with handgrip strength but not with muscle mass or length of hospital stay after hip fracture. Nutrition 2015, 31, 931-934. [CrossRef]

35. Dhanwal, D.K.; Dharmshaktu, P.; Gautam, V.K.; Gupta, N.; Saxena, A. Hand Grip Strength and Its Correlation with Vitamin D in Indian patients with hip fracture. Arch. Osteoporos. 2013, 8. [CrossRef]

36. Borim, F.S.A.; da Alexandre, T.S.; Neri, A.L.; de Máximo, R.O.; Silva, M.F.; de Oliveira, C. Combined effect of dynapenia (Muscle Weakness) and low vitamin d status on incident disability. J. Am. Med Dir. Assoc. 2019, 20, 47-52. [CrossRef]

37. Granlund, L.; Norberg, M.; Ramnemark, A.; Andersson, C.; Lindkvist, M.; Fhärm, E. Vitamin D is associated with lower limb muscle strength and grip strength in middle eastern- and African-born immigrants in Sweden. Nutr. Res. 2018, 59, 29-35. [CrossRef]

38. Wang, J.; Wang, X.; Gu, Y.; Liu, M.; Chi, V.T.Q.; Zhang, Q.; Liu, L.; Meng, G.; Yao, Z.; Wu, H.; et al. Vitamin D is related to handgrip strength in adult men aged 50 years and over: A population study from the TCLSIH cohort study. Clin. Endocrinol. 2019, 90, 753-765. [CrossRef] [PubMed]

39. Aspell, N.; Laird, E.; Healy, M.; Lawlor, B.; O'sullivan, M. Vitamin D deficiency is associated with impaired muscle strength and physical performance in community-dwelling older adults: Findings from the english longitudinal study of ageing. Clin. Interv. Aging 2019, 14, 1751-1761. [CrossRef] [PubMed] 
40. Houston, D.K.; Cesari, M.; Ferrucci, L.; Cherubini, A.; Maggio, D.; Bartali, B.; Johnson, M.A.; Schwartz, G.G.; Kritchevsky, S.B. Association between vitamin d status and physical performance: The InCHIANTI study. J. Gerontol. 2007, 62, 440-446. [CrossRef]

41. Avilés-Santa, M.L.; Monroig-Rivera, A.; Soto-Soto, A.; Lindberg, N.M. Current state of diabetes mellitus prevalence, awareness, treatment, and control in latin America: Challenges and innovative solutions to improve health outcomes across the continent. Curr. Diabetes Rep. 2020, 20. [CrossRef]

42. Villani, A.; McClure, R.; Barrett, M.; Scott, D. Diagnostic differences and agreement between the original and revised european working group (EWGSOP) consensus definition for sarcopenia in community-dwelling older adults with type 2 diabetes mellitus. Arch. Gerontol. Geriatr. 2020, 89. [CrossRef] [PubMed]

43. Cetinus, E.; Buyukbese, M.A.; Uzel, M.; Ekerbicer, H.; Karaoguz, A. Hand grip strength in patients with type 2 diabetes mellitus Diabetes Res. Clin. Pract. 2005, 70, 278-286. [CrossRef] [PubMed]

44. Nakamura, M.; Inaba, M.; Yamada, S.; Ozaki, E.; Maruo, S.; Okuno, S.; Imanishi, Y.; Kuriyama, N.; Watanabe, Y.; Emoto, M.; et al Association of decreased handgrip strength with reduced cortical thickness in Japanese female patients with Type 2 Diabetes mellitus. Sci. Rep. 2018, 8. [CrossRef]

45. Chow, S.; Shao, J.W.H. Sample Size Calculations in Clinical Research, 2nd ed.; Chapman \& Hall/CRC Biostatistics Series: Boca Raton, Florida, USA, 2008.

46. Guigoz, Y.; Vellas, B.; Garry, P.J. Assessing the nutritional status of the elderly: The mini nutritional assessment as part of the geriatric evaluation. Nutr. Rev. 1996, 54, S59-S65. [CrossRef]

47. Vellas, B.; Villars, H.; Abellan, G.; Soto, M.E.; Rolland, Y.; Guigoz, Y.; Morley, J.E.; Chumlea, W.; Salva, A.; Rubenstein, L.Z.; et al. Overview of the MNA-Its history and challenges. J. Nutr. Health Aging 2006, 10, 456-463. [PubMed]

48. Habicht, J.-P. Estandarización de métodos epidemiológicos cuantitativos sobre El terreno. Boletín Oficina Sanit. Panam. 1974, $76,375-384$.

49. Lohman, T.G.; Roche, A.F.; Martorell, R. Anthropometric Standardization Reference Manual; Illustrated; Human Kinetics Publishers: Champaign, IL, USA, 1988.

50. World Health Organization. Physical Status: The Use and the Interpretation of Anthropometry, 854th ed.WHO Technical Report Series:: Geneva, Switzerland, 1995.

51. World Health Organization. Report of a Consultation on Obesity. Obesity Preventing and Managing the Global Epidemic; World Health Organization: Geneva, Switzerland, 1998.

52. Lipschitz, D.A. Screening for nutritional status in the elderly. Prim. Care 1994, 1, 55-67.

53. Baumgartner, R.N.; Koehler, K.M.; Gallagher, D.; Romero, L.; Heymsfield, S.B.; Ross, R.R.; Garry, P.J.; Lindeman, R.D. Epidemiology of Sarcopenia among the Elderly in New Mexico. Am. J. Epidemiol. 1998, 147, 755-763. [CrossRef]

54. Cruz-Jentoft, A.J.; Bahat, G.; Bauer, J.; Boirie, Y.; Bruyère, O.; Cederholm, T.; Cooper, C.; Landi, F.; Rolland, Y.; Sayer, A.A.; et al. Sarcopenia: Revised European consensus on definition and diagnosis. Age Ageing 2019, 48, 16-31. [CrossRef]

55. Mahoney, F.I.; Barthel, D.W. Fuctional evaluation: The barthel index. Md. State Med. J. 1965, 14, 61-65. [PubMed]

56. Haslam, A.; Johnson, M.A.; Hausman, D.B.; Cress, M.E.; Houston, D.K.; Davey, A.; Poon, L.W. Vitamin d status is associated with grip strength in Centenarians. J. Nutr. Gerontol. Geriatr. 2014, 33, 35-46. [CrossRef] [PubMed]

57. Agergaard, J.; Trøstrup, J.; Uth, J.; Iversen, J.V.; Boesen, A.; Andersen, J.L.; Schjerling, P.; Langberg, H. Does Vitamin-D intake during resistance training improve the skeletal muscle hypertrophic and strength response in young and elderly men?-A Randomized controlled trial. Nutr. Metab. 2015, 12. [CrossRef] [PubMed]

58. DeLuca, H.F. History of the discovery of vitamin D and its active metabolites. Bonekey Rep. 2014, 3. [CrossRef] [PubMed]

59. Shinchuk, L.; Holick, M.F. Vitamin D and rehabilitation: Improving functional outcomes. Nutr. Clin. Pract. 2007, 22, 297-304. [CrossRef] [PubMed]

60. Garcia, L.A.; King, K.K.; Ferrini, M.G.; Norris, K.C.; Artaza, J.N. 1,25(OH)2 Vitamin D3 stimulates myogenic differentiation by inhibiting cell proliferation and modulating the expression of promyogenic growth factors and myostatin in C2C12 skeletal muscle cells. Endocrinology 2011, 152, 2976-2986. [CrossRef]

61. Sikora-Klak, J.; Narvy, S.J.; Yang, J.; Makhni, E.; Kharrazi, F.D.; Mehran, N. The Effect of abnormal vitamin D levels in athletes. Perm. J. 2018, 22, 17-216. [CrossRef]

62. Pojednic, R.M.; Ceglia, L. The Emerging biomolecular role of Vitamin D in skeletal muscle. Exerc. Sports Sci. Rev. 2014, 42, 76-81. [CrossRef]

63. Bischoff-Ferrari, H.A. Relevance of Vitamin D in muscle health. Rev. Endocr. Metab. Disord. 2012, 13, 71-77. [CrossRef]

64. Manoy, P.; Yuktanandana, P.; Tanavalee, A.; Anomasiri, W.; Ngarmukos, S.; Tanpowpong, T.; Honsawek, S. Vitamin D Supplementation improves quality of life and physical performance in osteoarthritis patients. Nutrients 2017, 9, 799. [CrossRef] [PubMed]

65. Zhu, K.; Austin, N.; Devine, A.; Bruce, D.; Prince, R.L. A randomized controlled trial of the effects of Vitamin D on muscle strength and mobility in older women with Vitamin D insufficiency. J. Am. Geriatr. Soc. 2010, 58, 2063-2068. [CrossRef] [PubMed]

66. Rosendahl-Riise, H.; Spielau, U.; Ranhoff, A.H.; Gudbrandsen, O.A.; Dierkes, J. Vitamin D supplementation and its influence on muscle strength and mobility in community-dwelling older persons: A systematic review and meta-analysis. J. Hum. Nutr. Diet. 2017, 30, 3-15. [CrossRef] [PubMed]

67. de la Cruz-Góngora, V.; Martínez-Tapia, B.; Cuevas-Nasu, L.; Flores-Aldana, M.; Shamah-Levy, T. Dietary intake and adequacy of energy and nutrients in mexican older adults: Results from two national health and nutrition surveys. Salud Publica Mex. 2017, 59, 285-298. [CrossRef] [PubMed] 
68. Wagatsuma, A.; Sakuma, K. Vitamin D signaling in myogenesis: Potential for treatment of sarcopenia. Biomed Res. Int. 2014, 2014, 121254. [CrossRef] [PubMed]

69. Bischoff-Ferrari, H.A.; Borchers, M.; Gudat, F.; Dürmüller, U.; Stähelin, H.B.; Dick, W. Vitamin D receptor expression in human muscle tissue decreases with age. J. Bone Miner. Res. 2004, 19, 265-269. [CrossRef]

70. Bischoff, H.A.; Borchers, M.; Gudat, F.; Duermueller, U.; Theiler, R.; Stähelin, H.B.; Dick, W. In situ detection of 1,25dihydroxyvitamin D3 Receptor in human skeletal muscle tissue. Histochem. J. 2001, 33, 19-24. [CrossRef] [PubMed]

71. Karimi Kinyamu, H.; Gallagher, J.C.; Prahl, J.M.; Deluca, H.F.; Petranick, K.M.; Lanspa, S.J. Association between intestinal vitamin $\mathrm{d}$ receptor, calcium absorption, and serum 1,25 Dihydroxyvitamin D in normal young and elderly women. J. Bone Miner. Res. 1997, 12, 922-928. [CrossRef] [PubMed]

72. Holick, M.F.; Chen, T.C.; Lu, Z.; Sauter, E. Vitamin D and skin physiology: A D-lightful story. J. Bone Miner. Res. 2007, 22, V28-V33. [CrossRef]

73. Hagenau, T.; Vest, R.; Gissel, T.N.; Poulsen, C.S.; Erlandsen, M.; Mosekilde, L.; Vestergaard, P. Global Vitamin D levels in relation to age, gender, skin pigmentation and latitude: An ecologic meta-regression analysis. Osteoporos. Int. 2009, 20, 133-140. [CrossRef] [PubMed]

74. Guigoz, Y.; Vellas, B. The Mini Nutritional Assessment (MNA) for grading the nutritional state of elderly patients: Presentation of the MNA, history and validation. Nestlé Nutr. Workshop Ser. Clin. Perform. Programme 1999, 1, 3-12. [PubMed]

75. Tsagari, A.; Toulis, K.A.; Makras, P.; Skagias, K.; Galanos, A.; Lyritis, G. Performance of the mini nutritional assessment score in the detection of Vitamin D status in an elderly greek population. Horm. Metab. Res. 2012, 44, 896-899. [CrossRef] [PubMed]

76. Crowe, F.L.; Steur, M.; Allen, N.E.; Appleby, P.N.; Travis, R.C.; Key, T.J. Plasma concentrations of 25-Hydroxyvitamin D in meat eaters, fish eaters, vegetarians and vegans: Results from the EPIC-Oxford study. Public Health Nutr. 2011, 14, 340-346. [CrossRef]

77. Madeira, T.; Severo, M.; Oliveira, A.; Gorjão Clara, J.; Lopes, C. The association between dietary patterns and nutritional status in community-dwelling older adults—the PEN-3S study. Eur. J. Clin. Nutr. 2020. [CrossRef] [PubMed]

78. Nakamura, K.; Kitamura, K.; Watanabe, Y.; Saito, T.; Takahashi, A.; Kobayashi, R.; Oshiki, R.; Kabasawa, K.; Takachi, R.; Tsugane, S.; et al. Predictors of decline in vitamin d status in middle-aged and elderly individuals: A 5-year follow-up study. Br. J. Nutr. 2020, 124, 729-735. [CrossRef]

79. Mariam, W.; Garg, S.; Singh, M.M.; Koner, B.C.; Anuradha, S.; Basu, S. Vitamin D status, determinants and relationship with biochemical profile in women with type 2 diabetes mellitus in Delhi, India. Diabetes Metab. Syndr. Clin. Res. Rev. 2019, 13, 1517-1521. [CrossRef]

80. Raška, I.; Rašková, M.; Zikán, V.; Škrha, J. High prevalence of Hypovitaminosis D in postmenopausal women with type 2 Diabetes mellitus. Prague Med Rep. 2016, 117, 5-17. [CrossRef] [PubMed]

81. Vujosevic, S.; Borozan, S.; Radojevic, N.; Aligrudic, S.; Bozovic, D. Relationship between 25-Hydroxyvitamin D and Newly diagnosed type 2 diabetes mellitus in postmenopausal women with osteoporosis. Med Princ. Pract. 2014, 23, 229-233. [CrossRef]

82. Al-Daghri, N.M.; Alkharfy, K.M.; Al-Othman, A.; El-Kholie, E.; Moharram, O.; Alokail, M.S.; Al-Saleh, Y.; Sabico, S.; Kumar, S.; Chrousos, G.P. Vitamin D supplementation as an adjuvant therapy for patients with T2DM: An 18-month prospective interventional study. Cardiovasc. Diabetol. 2012, 11, 1-7. [CrossRef] [PubMed]

83. Deleskog, A.; Hilding, A.; Brismar, K.; Hamsten, A.; Efendic, S.; Östenson, C.G. Low serum 25-Hydroxyvitamin D level predicts progression to type 2 diabetes in individuals with prediabetes but not with normal glucose tolerance. Diabetologia 2012, 55, 1668-1678. [CrossRef] [PubMed]

84. Hurskainen, A.R.; Virtanen, J.K.; Tuomainen, T.P.; Nurmi, T.; Voutilainen, S. Association of Serum 25-Hydroxyvitamin D with Type 2 diabetes and markers of insulin resistance in a general older population in Finland. Diabetes/Metab. Res. Rev. 2012, 28, 418-423. [CrossRef] [PubMed]

85. Bland, R.; Markovic, D.; Hills, C.E.; Hughes, S.V.; Chan, S.L.F.; Squires, P.E.; Hewison, M. Expression of 25-Hydroxyvitamin D3-1 $\alpha$-Hydroxylase in Pancreatic Islets. J. Steroid Biochem. Mol. Biol. 2004, 89-90, 121-125. [CrossRef] [PubMed]

86. Labriji-Mestaghanmi, H.; Billaudel, B.; Garnier, P.E.; Malaisse, W.J.; Sutter, B.C.J. Vitamin D and pancreatic islet function, I. Time course for changes in insulin secretion and content during vitamin D deprivation and repletion. J. Endocrinol. Investig. 1988, 11, 577-584. [CrossRef] [PubMed]

87. Srikanth, P.; Chun, R.F.; Hewison, M.; Adams, J.S.; Bouillon, R.; Vanderschueren, D.; Lane, N.; Cawthon, P.M.; Dam, T.; BarrettConnor, E.; et al. Associations of total and free 25OHD and 1,25(OH)2D with serum markers of inflammation in older men. Osteoporos. Int. 2016, 27, 2291-2300. [CrossRef] [PubMed] 